\title{
Sustainable Treatment of Food Industry Wastewater Using Membrane Technology: A Short Review
}

\author{
Md. Nahid Pervez ${ }^{1}$, Monira Rahman Mishu ${ }^{2}$, George K. Stylios ${ }^{3}{ }^{(}$, Shadi W. Hasan ${ }^{4}$, Yaping Zhao ${ }^{5}$, \\ Yingjie Cai ${ }^{6}$, Tiziano Zarra ${ }^{1}$, Vincenzo Belgiorno ${ }^{1}$ and Vincenzo Naddeo ${ }^{1, *}$ (I) \\ 1 Sanitary Environmental Engineering Division (SEED), Department of Civil Engineering, University of \\ Salerno, via Giovanni Paolo II 132, 84084 Fisciano, SA, Italy; perveznahidmd@gmail.com (M.N.P.); \\ tzarra@unisa.it (T.Z.); v.belgiorno@unisa.it (V.B.) \\ 2 Faculty of Nutrition and Food Science, Patuakhali Science and Technology University, \\ Patuakhali 8602, Bangladesh; monirarmishu@gmail.com \\ 3 Research Institute for Flexible Materials, School of Textiles and Design, Heriot-Watt University, \\ Galashiels TD1 3HF, UK; g.stylios@hw.ac.uk \\ 4 Center for Membranes and Advanced Water Technology (CMAT), Department of Chemical Engineering, \\ Khalifa University of Science and Technology, Abu Dhabi 127788, United Arab Emirates; \\ shadi.hasan@ku.ac.ae \\ 5 Institute of Eco-Chongming, School of Ecological and Environmental Sciences, East China Normal University, \\ Shanghai 200241, China; ypzhao@des.ecnu.edu.cn \\ 6 Hubei Provincial Engineering Laboratory for Clean Production and High Value Utilization of Bio-Based \\ Textile Materials, Wuhan Textile University, Wuhan 430200, China; yingjiecai@wtu.edu.cn \\ * Correspondence: vnaddeo@unisa.it; Tel.: +39-089-96-6333
}

Citation: Pervez, M.N.; Mishu, M.R.; Stylios, G.K.; Hasan, S.W.; Zhao, Y.; Cai, Y.; Zarra, T.; Belgiorno, V.;

Naddeo, V. Sustainable Treatment of Food Industry Wastewater Using Membrane Technology: A Short Review. Water 2021, 13, 3450. https://doi.org/10.3390/w13233450

Academic Editor:

Jesus Gonzalez-Lopez

Received: 19 October 2021

Accepted: 2 December 2021

Published: 5 December 2021

Publisher's Note: MDPI stays neutral with regard to jurisdictional claims in published maps and institutional affiliations.

Copyright: (c) 2021 by the authors. Licensee MDPI, Basel, Switzerland. This article is an open access article distributed under the terms and conditions of the Creative Commons Attribution (CC BY) license (https:/ / creativecommons.org/licenses/by/ $4.0 /)$.

\begin{abstract}
Water is needed for food processing facilities to carry out a number of tasks, including moving goods, washing, processing, and cleaning operations. This causes them to produce wastewater effluent, and they are typically undesirable since it contains a high volume of suspended solids, bacteria, dyestuffs, salts, oils, fats, chemical oxygen demand and biological oxygen demand. Therefore, treatment of food industry wastewater effluent is critical in improving process conditions, socio-economic benefits and our environmental. This short review summarizes the role of available membrane technologies that have been employed for food wastewater treatment and analyse their performance. Particularly, electrospun nanofiber membrane technology is revealed as an emerging membrane science and technology area producing materials of increasing performance and effectiveness in treating wastewater. This review reveals the challenges and perspectives that will assist in treating the food industry wastewater by developing novel membrane technologies.
\end{abstract}

Keywords: food industry wastewater; membrane processes; electrospun nanofiber membranes; fouling

\section{Introduction}

Increased population growth and urbanization have led to water scarcity around the world. Literature data shows that industrial sectors use 4 trillion cubic meters of water per annum, while clean water for daily human consumption is estimated at around 0.01 trillion cubic meters [1-5]. There is an urgent need to find new clean water supply resources from various sectors such as rainwater, saline water and wastewater. A considerable amount of industrial wastewater being directly discharged into the natural environment causes severe problems for human health and the ecosystem [6-9]. Therefore, industrial wastewater treatment would be a feasible solution to overcome the freshwater shortage and contribute to the sustainability of our environment.

Food industry along with textiles and other industries has been recognized as one of the major water consumers and for generating wastewater. Water consumption is needed for the processing of raw material and for washing, heating, and cooling stages of its use $[10,11]$. Furthermore, it has been pointed out that the utility part is the main contributor 
to large volumes of annual wastewater generation [12]. Studies showed that effluents from the food processing industry contain complex compounds which are difficult to remove $[13,14]$, hence, requiring efficient treatment technologies. There are numerous methods which have been applied to treat food industry wastewater such as physical-chemical systems (coagulation, filtration, evaporation, centrifugation and gravity concentration) [15], adsorption [16], Fenton oxidation [17,18], ozone [19], microalgae cultivation [20], constructed wetlands [21], UV disinfection [22], plasma [23], microbial fuel cells (MFCs) [24], etc. However, their high operation cost and the generation of secondary pollutants have limited their applications [25-27].

Recently, there has been a growing interest in developing environmentally friendly, cost-effective, and efficient treatment systems for the treatment of food industry wastewater. Membrane processes show great potential owing to their unique advantages, such as high-quality effluent performance, less energy required, and easy operation [28]. There are various types of membrane operations such as membrane bioreactors (MBRs), pressuredriven membrane filtration (microfiltration (MF), ultrafiltration (UF), nanofiltration (NF), and reverse osmosis (RO)), forward osmosis (FO), electrodialysis (ED), membrane contactors and membrane distillation (MD) [29]. Membranes are fabricated through several methods, including phase inversion [30,31], sintering [32], track-etching [33] and wet spinning [34]. However, these processes showed several environmental concerns, high operational costs, and availability.

Meanwhile, it has been discussed in the scientific community that fabrication tuning strategy has played a vital role in improving the performance of membrane processes. Electrospinning is a versatile technique for the fabrication of nanofibers membranes with less than $100 \mathrm{~nm}[35,36]$. Electrospun membranes, generally termed nanofibers membranes, show great promise in water treatment applications due to their outstanding features such as high surface area, mechanical robustness, small pores, porosity, and lightweight [37]. Several studies were reported in literature for the application of electrospun nanofibers in MBRs [38,39], MF [40], UF [41], NF [42], RO [43], ED [44], MD [45], membrane contactors [46] and FO [47]. We believe that writing a short review on the applications of electrospun nanofiber membranes in the food industry wastewater treatment is essential to state the current status of the research progress and its future potential suggesting research directions for further developments.

To the best of our knowledge, there are no papers demonstrating the effect of conventional membranes and new generation membranes such as electrospun nanofiber membranes for food industry wastewater treatment. Therefore, the main goal of this short review is to analyze the reported studies in the literature over the previous decades with a general overview of food industry wastewater and focusing on the performance of conventional membrane processes. Then, the current developments of electrospun nanofiber membranes for the treatment of food industry wastewater will be critically discussed, which are also supported by experimental investigations. Lastly, this review will cover the major challenges in membrane processes such as membrane fouling with mitigation strategies and finally provide recommendations and future perspectives.

\section{Characteristics of Food Industry Wastewater}

It is known that several types of food processing industries are available due to the demand for diverse food choices. As a result, each industry produces a significant amount of organic-rich wastewater effluents. Examples include biological chemical oxygen (BOD), salts, fats, dyestuff, greases, oils, chemical oxygen demand (COD), total dissolved solids (TDS), and total suspended solids (TSS). Additional pollutants may also be present depending on raw materials and processing procedures [48]. Typical characteristics of food industry wastewater are presented in Table 1.

Tentative comparison of the wastewater parameters for different food industry sectors could be made by measuring their initial effluent quantity (Table 2). For instance, soybean processing industries generate 7 to 10 tons of wastewater in which various 
substances are found, such as amino acids, lipids, organic acids, vitamins, saponin, mono/oligosaccharides, whey protein, and COD amount remains 10 to $20 \mathrm{~g} / \mathrm{L}$ [49]. The dairy industry produces wastewater containing high concentration of solids and $50 \%$ are found in the volatile form. The typical concentration of COD ranges between 2 to $10 \mathrm{~g} / \mathrm{L}$, whereas nutrients (phosphorus and nitrogen) were present in very low concentrations when compared to other industries [50]. Similarly, oil mill industry wastewater effluent contains very low concentration of nitrogen, while phenolic compounds (long-chain fatty acids and tannins) are present in high concentrations [51]. In starch processing industries, carbon, nitrogen and phosphorus (330:30:1 in molar ratio) are present in higher concentrations with COD concentration ranging from 6 to $56 \mathrm{~g} / \mathrm{L}$ [52]. The wastewater effluent collected from other industries such as meat processing, winery and brewery has higher content of mineral compounds [53-55]. Direct discharge of food industrial wastewater effluents into the environment can cause human health problems because the presence of refractory organics at high concentrations are not easy to remove using a typical treatment process $[56,57]$. Thus, it is clear that the wastewater generated by all sectors of the food industry must be combated by using highly efficient treatment processes.

Table 1. Typical characteristics of food industry wastewater.

\begin{tabular}{cc}
\hline Common Parameters & Standard Volume (mg/L) \\
\hline Total suspended solids & 50 \\
Total nitrogen & 10 \\
Total Phosphorus & 2 \\
Biochemical oxygen demand & 50 \\
Chemical oxygen demand & 250 \\
Oil and grease & 10 \\
pH & $5.5-9.0$ \\
\hline
\end{tabular}

Table 2. Different types of food industries wastewater characteristics.

\begin{tabular}{|c|c|c|c|}
\hline Sources & Main Components of Wastewater & Characteristics & Ref \\
\hline Dairy & Proteins, detergents, lactose, and lipids & $\begin{array}{c}\mathrm{BOD}=442 \mathrm{mg} / \mathrm{L} \\
\mathrm{COD}=8960 \mathrm{mg} / \mathrm{L} \\
\mathrm{TDS}=253.6 \mathrm{mg} / \mathrm{L} \\
\mathrm{pH}=7.10 \\
\mathrm{BOD}=4426 \mathrm{mg} / \mathrm{L}\end{array}$ & [58] \\
\hline Olive mill & Phenols, pectin, sugars, fats, oil, salts and carbohydrates & $\begin{array}{c}\mathrm{COD}=55,730-156,000 \mathrm{mg} / \mathrm{L} \\
\text { Total phenol }=2439-8300 \mathrm{mg} / \mathrm{L} \\
\mathrm{pH}=5.6\end{array}$ & {$[59,60]$} \\
\hline Slaughterhouse & Nitrogen, sodium, potassium, calcium and fats & $\begin{array}{c}\mathrm{BOD}=1209 \mathrm{mg} / \mathrm{L} \\
\mathrm{COD}=4221 \mathrm{mg} / \mathrm{L} \\
\text { Total nitrogen }=427 \mathrm{mg} / \mathrm{L} \\
\mathrm{pH}=6.95 \\
\mathrm{BOD}=860 \mathrm{mg} / \mathrm{L}\end{array}$ & [61] \\
\hline Fruits & Carbohydrates, minerals, nitrogen phosphorus and salts & $\begin{array}{c}\mathrm{COD}=919 \mathrm{mg} / \mathrm{L} \\
\text { Total nitrogen }=40 \mathrm{mg} / \mathrm{L} \\
\mathrm{pH}=5.5-7.2\end{array}$ & [62] \\
\hline Seafood & Sodium chlorides, phosphorus, nitrogen, salts, fats and grease & $\begin{array}{c}\mathrm{BOD}=3250 \mathrm{mg} / \mathrm{L} \\
\mathrm{COD}=13,180 \mathrm{mg} / \mathrm{L} \\
\text { Salts }=2-5 \%(w / v) \\
\mathrm{pH}=5-7\end{array}$ & {$[63]$} \\
\hline
\end{tabular}

\section{Membrane Technologies for Food Wastewater Treatment}

In view of the adverse effects of food industries wastewater on the socio-economic development, environment and public health system, involving the generation of contaminants and solid particles free effluent is an important aspect before discharge. If the water quality meets particular regulatory standards, the treated wastewater may be re-used, giving an alternate method of reducing the strain on freshwater sources [64]. This section emphasizes on the use of various membrane-based technologies that have seen significant growth in treating food wastewater. 


\subsection{Membrane Bioreactor}

Membrane bioreactor (MBR) processes have proven to be quite effective in the removal of organic and inorganic contaminants from wastewaters. It has achieved growing popularity in recent years as a result of more strict environmental regulations and an increase in water reuse policies. The widespread use of MBR is attributable to its reliability, scalability, lower sludge generation, good efficiency, simplicity of operation, and smaller footprint [65]. MBRs wastewater treatment process is accomplished using a combined biological process (organic pollutant biodegradation) and filtration (accountable for the separation of treated water from solids effluent through the use of a membrane panel). Typically, anaerobic membrane bioreactors (AnMBRs) and aerobic membrane bioreactors (AMBRs) are the two categories of MBRs, which are distinguished by their arrangements and hydrodynamic regulation of permeate flux (Figure 1) [66]. With over 30 years of experience, this technology has provided the benefits of treating wastewater, as a result, MBRs are preferred over other techniques for obtaining high quality treated wastewater, such as activated carbon adsorption, filtration, and coagulation. Meanwhile, compared to conventional MBRs, integration of MBR with other technologies such as FO-MBR, MBR$\mathrm{RO} / \mathrm{NF}$, advanced oxidation processes (AOPs)/electrocoagulation-MBR are considered good potential candidates for wastewater treatment $[67,68]$.

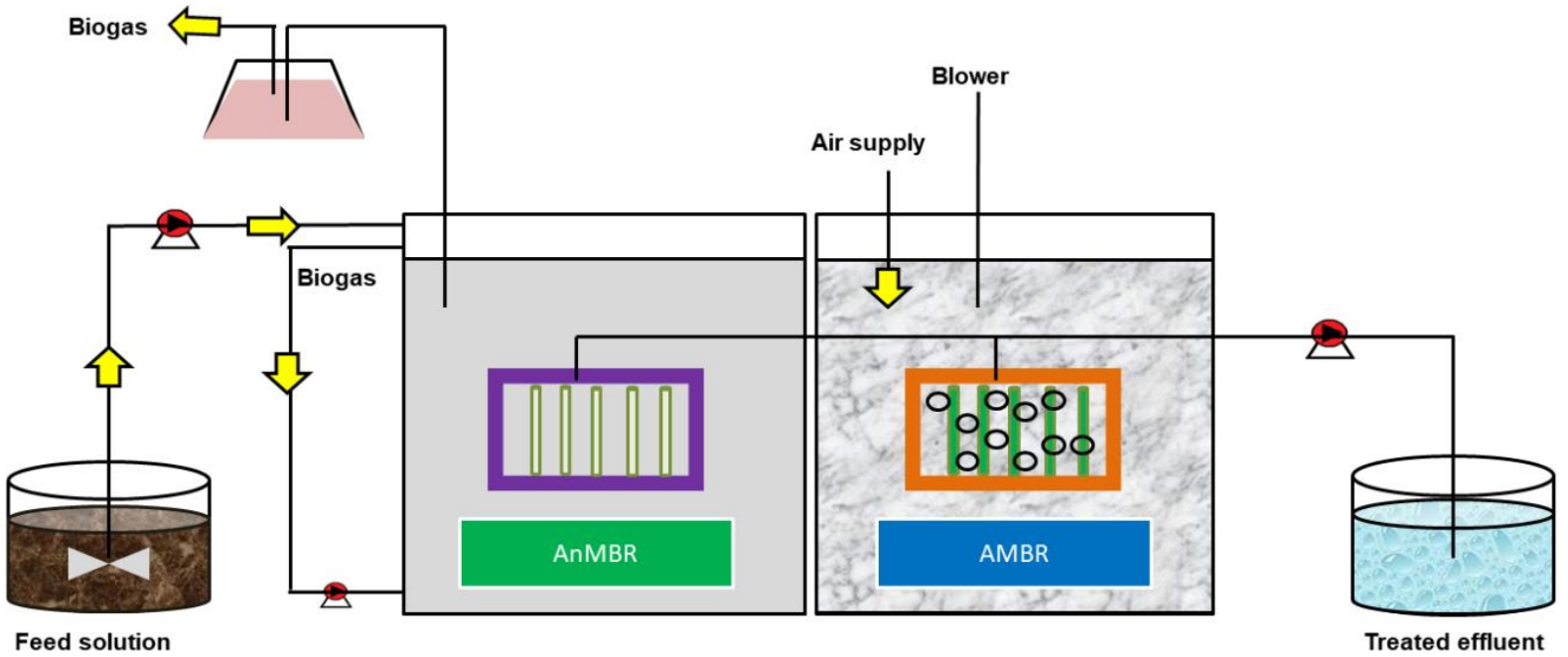

Figure 1. Typical representation of anaerobic MBR (AnMBR) and aerobic MBR (AMBR).

Several studies investigated the effectiveness of MBRs in treating wastewater from food industries. For instance, He et al. [69] have treated food wastewater with an AnMBR. This study used a higher strength food wastewater since it contains a high concentration of COD (more than $1000 \mathrm{mg} / \mathrm{L}$ ) and exhibited a high-efficiency COD removal rate (81-94\%). It was noticed that the volumetric loading rate (VLR) influences the efficiency through which high COD removals were obtained below $4.5 \mathrm{~kg} / \mathrm{m} 3 \mathrm{~d}$ of VLR [70,71]. Mixed liquor suspended solid (MLSS) concentration also influences the performance of MBRs during wastewater treatment. Katayon, S., et al. [72] achieved a higher removal rate of suspended solids (99.2\%) and turbidity $(99.73 \%)$ at a lower concentration of MLSS. However, some studies have recently introduced a two-stage AnMBR set-up to enhance food wastewater removal efficiency regardless of the effect of the operational parameters [73,74]. This two-stage scheme was proposed because of their crucial advantages such as stability and inhibition reduction of toxic compounds resulted in higher affinity between particles and membrane surface. A recent report also demonstrated that a two-stage dynamic AnMBR could be efficient for food wastewater treatment and found that in all cases, more than $90 \%$ of MLSS and total COD were successfully removed under stable operating conditions [75]. Thus, it can be speculated that the use of a designed modular MBRs operation may have high prospects to improve the effluent quality of food industry discharged wastewater. 


\subsection{Pressure-Driven Membrane Filtration}

The pressure-driven membrane filtration processes are now considered the most multifunctional and effective technologies for wastewater reclamation, providing a number of benefits such as easy installation, rapid execution and higher efficiency. In this process, the feed stream is loaded in the filtration unit equipped with a membrane panel and required pressure exerted immediately during the operation to separate into permeate and retentate solution [76]. The rejection behavior of membranes is especially important in this type of operation because it is responsible for eliminating large amounts of organic matter, micropollutants, and dyestuff from raw effluents, which results in high-quality permeate water for various uses including, soil/fertilizer growth, toilet flushing, household washing and watering gardens [77]. Membranes are classified into MF, UF, NF and RO (Figure 2).

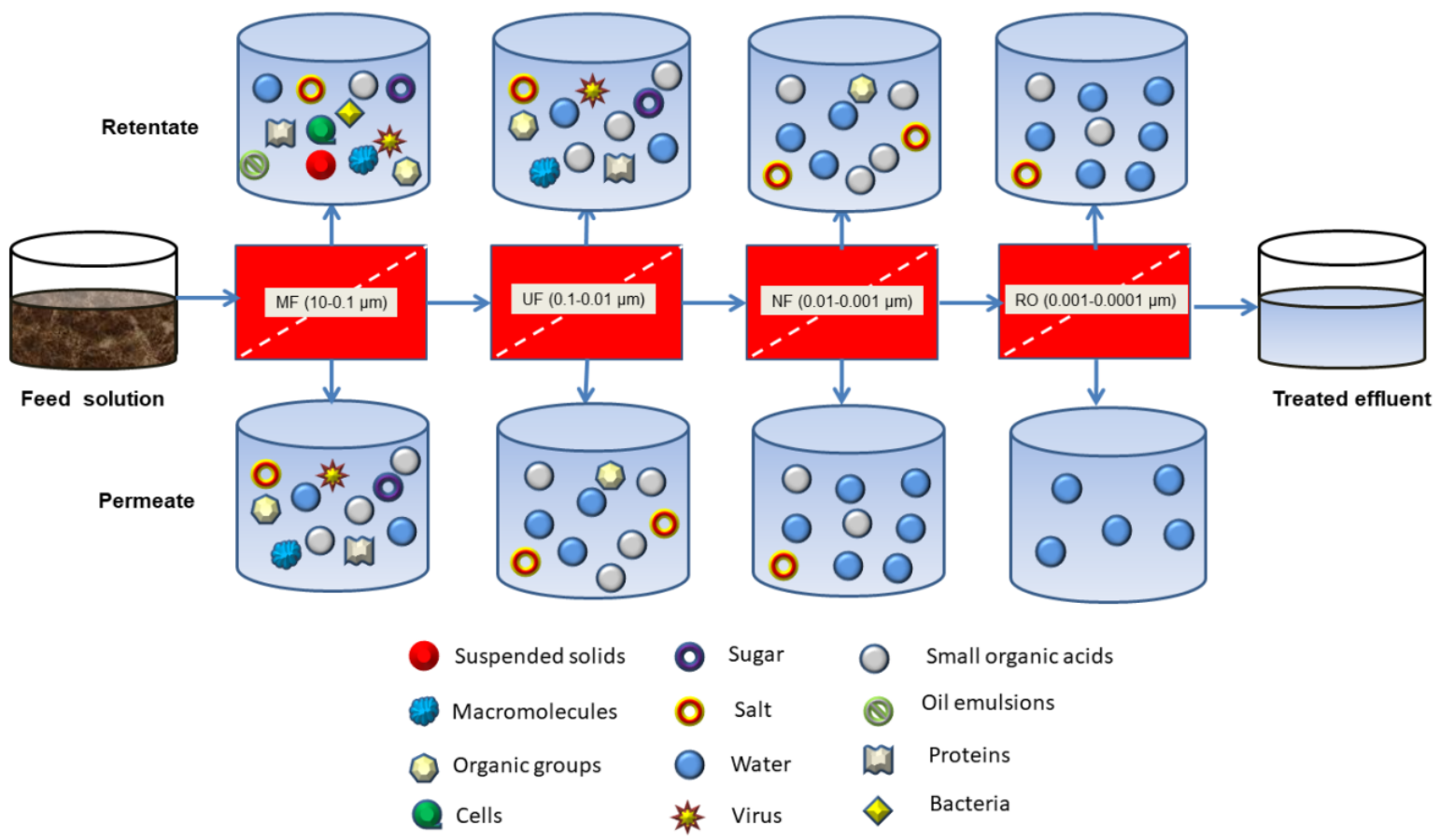

Figure 2. Typical representation of pressure-driven membrane process.

In MF, membranes with larger pores typically s with diameters of about $10-0.1 \mu \mathrm{m}$ and MWCOs ( $>100,000$ Daltons), can be effective for removing large, suspended solids, colloids, particles, and some types of bacteria. In this process, the operating pressure typically ranges from 0.1 to 2 bar. UF membranes with pore sizes ranging between 0.1 and 0.01 microns and molecular cutoff weight (MWCO) values ranging between 1000 and $100,000 \mathrm{Da}$ are used. As a result, this process has the capability to retain larger compounds such as polysaccharides, emulsions, proteins and colloidal particles. The operating pressure normally ranges from 0.1 to 5 bar. NF membranes lie between the UF and RO process, where the diameters of those membranes are $0.01-0.001 \mu \mathrm{m}$, equivalent to 200-1000 Da MWCO. They are usually employed to remove small molecular weight molecules (divalent ions, amino acids, organic acids, glucose and sugars). This is generally carried out at pressure ranges from 5 to 30 bar. $\mathrm{RO}$ is by far the most effective for removing dissolved salts, inorganic contaminants and chemical substances because of their smaller pore size in the range of $0.1-1 \mathrm{~nm}$ and MWCO, about $100 \mathrm{Da}$. It needs higher operating pressure, which typically runs between 20 and 65 bar.

Recently, greater emphasis has been made on the application of the pressure-driven membrane filtration process in food wastewater treatment (Table 3) $[78,79]$. Generally, MF has been shown to produce particle free solutions from dairy wastewater effluents due to their larger pore size. It is known that the presence of solid particles may block 
the membrane pores, which hinders the removal percentages of pollutants from the food wastewater using membrane filtration. Hence, some studies used ceramic MF membrane and found that up to $90 \%$ of solids particles could be removed from various food industrial wastewater processes, accompanying much clear permeate effluent quality [80-82]. These studies demonstrated that the MF process could be an effective pretreatment step for the next membrane filtration process, such as UF. For instance, Zielińska et al. [83] conducted an experimental study with MF and UF alone, and with UF/MF combined to treat dairy wastewater. Results showed that MF alone could remove $89 \pm 2 \%$ COD while using the UF process, the removal efficiency of COD increased to $95 \pm 1 \%$. This is attributed to the sieve retention mechanism, in which particles are retained on the membrane surface, and these differences were based on MWCO. UF was found to have a higher COD removal ability due to the lower cut-off value of the UF compared to the MF membrane [84].

Table 3. Performance of pressure-driven membrane filtration for food industry wastewater treatment.

\begin{tabular}{|c|c|c|c|c|}
\hline Type of Membrane Filtration & Source & Characteristics & Performance & Ref \\
\hline MF & Dairy wastewater & $\begin{array}{c}\mathrm{BOD}=890 \pm 92 \mathrm{mg} / \mathrm{L} \\
\mathrm{COD}=3536 \pm 328 \mathrm{mg} / \mathrm{L} \\
\text { Turbidity }=623 \pm 140 \mathrm{NTU} \\
\mathrm{TSS}=1860 \pm 220 \mathrm{mg} / \mathrm{L} \\
\mathrm{pH}=7.3 \pm 0.3\end{array}$ & $\begin{array}{c}\text { COD Removal }(\%)=89 \pm 2 \\
\text { Color Removal }(\%)=93 \pm 5 \\
\text { Turbidity Removal }(\%)=98 \pm 4\end{array}$ & [83] \\
\hline UF & Dairy wastewater & $\begin{array}{c}\mathrm{BOD}=890 \pm 92 \mathrm{mg} / \mathrm{L} \\
\mathrm{COD}=3536 \pm 328 \mathrm{mg} / \mathrm{L} \\
\text { Turbidity }=623 \pm 140 \mathrm{NTU} \\
\mathrm{TSS}=1860 \pm 220 \mathrm{mg} / \mathrm{L} \\
\mathrm{pH}=7.3 \pm 0.3 \\
\mathrm{BOD}=816.17-1097.25 \mathrm{mg} / \mathrm{L}\end{array}$ & $\begin{array}{c}\text { COD Removal }(\%)=95 \pm 1 \\
\text { Color Removal }(\%)=97 \pm 6 \\
\text { Turbidity Removal }(\%)=99 \pm 5\end{array}$ & [83] \\
\hline NF & Restaurant wastewater & $\begin{array}{c}\mathrm{COD}=10,356.67-16,443.33 \mathrm{mg} / \mathrm{L} \\
\text { Turbidity }=402.67-1208 \mathrm{NTU} \\
\text { TSS }=1860 \pm 220 \mathrm{mg} / \mathrm{L} \\
\mathrm{pH}=4.49-6.15\end{array}$ & $\begin{array}{c}\text { COD Removal }(\%)=99.4 \\
\text { BOD Removal }(\%)=86.8 \\
\text { Turbidity Removal }(\%)=99.9\end{array}$ & [85] \\
\hline $\mathrm{RO}$ & Olive wastewater & $\begin{array}{c}\text { Suspended } \\
\text { matter }=14-16 \mathrm{mg} / \mathrm{L} \\
\mathrm{COD}=120.5-226.6 \mathrm{mg} / \mathrm{L}\end{array}$ & COD Removal $(\%)=99.8$ & [86] \\
\hline
\end{tabular}

This observation highlights the importance of MF/UF membranes for the removal of high-molecular-weight contaminants rather than dissolved ions, whereas NF or RO would be more appropriate for ion rejection. The effluent quality turned out to be standard after being subjected to the NF process followed by the UF process. Zulaikha et al. [85] treated restaurant wastewater effluent through sequential filtration from UF to NF and obtained similar removal percentages of COD $(97.8 \%)$ and turbidity (9.9\%). However, a significant reduction in BOD5 and conductivity were observed under the NF operation, which indicates that the incorporation of NF membranes is potentially suitable for the production of fit-for-purpose water. In contrast to NF, RO has a high selectivity for impurities in the water. NF membranes are well-known for their ability to reject almost all impurities in the water, particularly multivalent ions. The management of food industry wastewater through the use of $\mathrm{RO}$ has been investigated due to its scalability and stringent water reuse environmental regulations and standards [86]. When comparing the removal efficiency between NF and $\mathrm{RO}$, it was noticed that the maximum COD removal reached values up to $60 \%$ for NF while $\mathrm{RO}$ removed more than $95 \%$ of COD and multivalent ions, indicating that pore size and membrane surface charge plays a significant role in purifying effluents $[87,88]$. However, having set a goal of obtaining high-quality permeate water, some observations still need to be considered. Among these are factors associated with NF/RO membranes and the pretreatment stage are highly recommended in $\mathrm{RO} / \mathrm{NF}$ application. Moreover, when complex chemical compounds including organic acids, polyphenols, and other substances are present in food industrial wastewater effluents their recovery/concentration, is a significant benefit to the economic and environmental impact of effluents by pressure-driven membrane filtration technology [89]. 


\subsection{Membrane Distillation}

$\mathrm{MD}$ is a thermally-driven process that uses a hydrophobic membrane to separate feed and permeate solutions. The MD process is operated by the difference in vapour pressure caused by the temperature variation throughout the membrane surface. The hydrophobic nature of the membrane allows only vapour to pass through, leaving liquid on the feed side and preventing it from entering the membrane pores (Figure 3) $[90,91]$. There are a number of benefits to the MD process. It can be performed at less pressure and temperatures than the feed solution boiling point. Due to the pore volume in the microporous membrane, the MD process demands less vapour space while a traditional distillation column requires a large vapour space. It allows a very high non-volatile solvent separating factor and can also be used to concentrate aqueous solutions or to produce high purity water. It can make use of any level of low waste heat, which can then be used in conjunction with solar energy, making it a viable option for the supply of freshwater from brackish water in regions where their lack of water supply $[92,93]$.

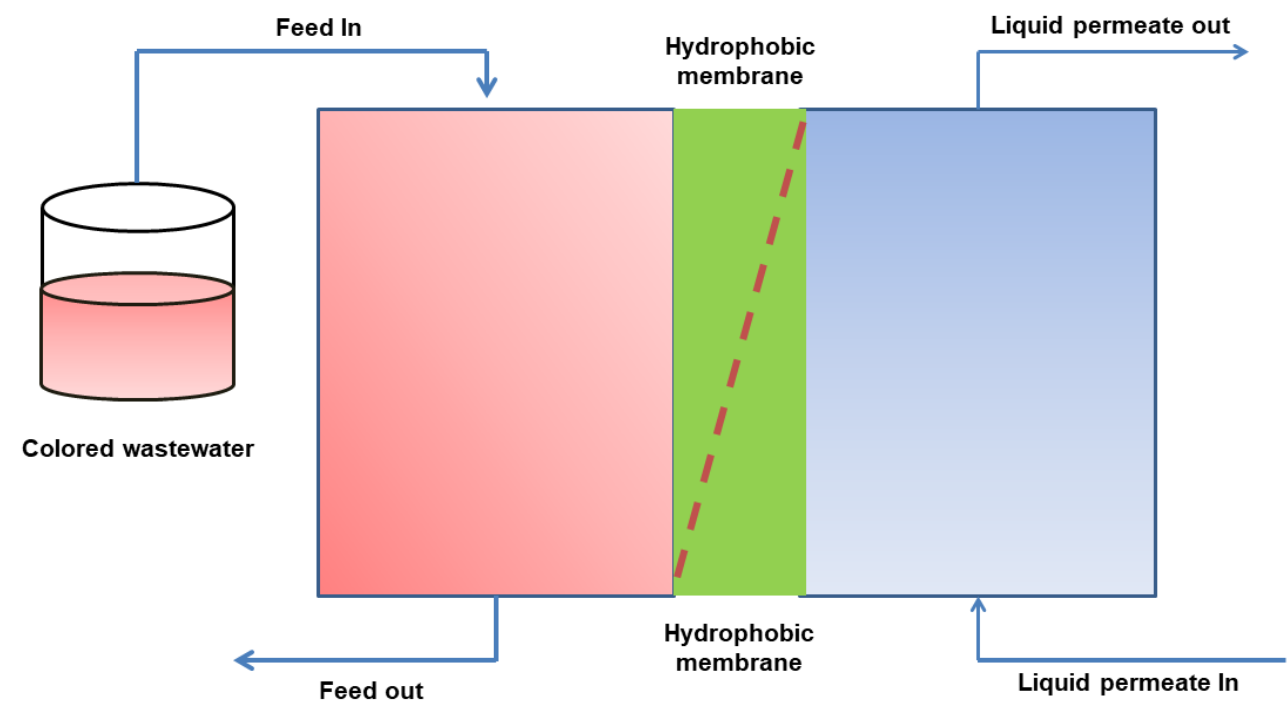

Figure 3. Representative diagram of the membrane distillation process.

Due to these advantages, MD has received significant attention in the treatment of food industry wastewater. Researchers have developed several types of MD configurations, including direct contact MD (DCMD), which has frequently been used in treating olive mill wastewater. The use of DCMD in olive mill wastewater treatment has the potential to recover the phenolic compounds in the concentrate because it is a non-destructive technique towards the phenol content [94]. In the DCMD system, El-Abbassi et al. [95] used commercially available flat sheet polytetrafluoroethylene (PTFE) membranes (TF200, Gelman) having pore size around $0.2 \mu \mathrm{m}$ to treat real olive wastewater in Morocco. Results showed that no effect was observed on the phenolic content and antioxidant ability when DCMD was applied at $80^{\circ} \mathrm{C}$. Notably, it was discovered that PTFE membranes had a better polyphenols recovery efficiency (99\%) than PVDF membranes (89\%) [95]. Nevertheless, DCMD's limit on permeate flux and flux reduction remain unchanged. However, these challenges may be overcome by applying an integrated MD system such as osmotic MD [96], MF/NF integrated MD system [97]. These studies showed that pretreatment technologies (MF/NF) play a significant role in enhancing the treatment efficiency by removing solid particles, resulting in a high permeate quality effluent.

\subsection{Electrodialysis}

ED, proven technology for water desalination, acid and basic production, can reduce toxicity and separate ionic and non-ionic species from industrial effluents under the influence of applied electric potential. In principle, the conventional ED (CED) structure 
consists of alternating arrangements between anode and cathode, with multiple cation exchange membranes (CCEM) and anion exchange membranes (AEM). Anions can pass through anion membranes (AEM); however, they cannot pass through membranes for cation exchange (CEM). Cations can likewise pass through a CEM and not an AEM membrane (Figure 4) [98]. In addition, a unique form of membrane called bipolar is used in an ED field. Bipolar membranes are composed of cation laminate and a layer of anion exchange [99]. These membranes, when using an electrical potential, ensure that an electric charge is transported via protons and water splitting hydroxyl ions. The ED process shows a greater rate of water recovery, reduced operating cost, easier operation and membrane stability compared to RO. Therefore, the use of ED technology has piqued the scientific community's interest because it is economical and efficient in water effluent [100].

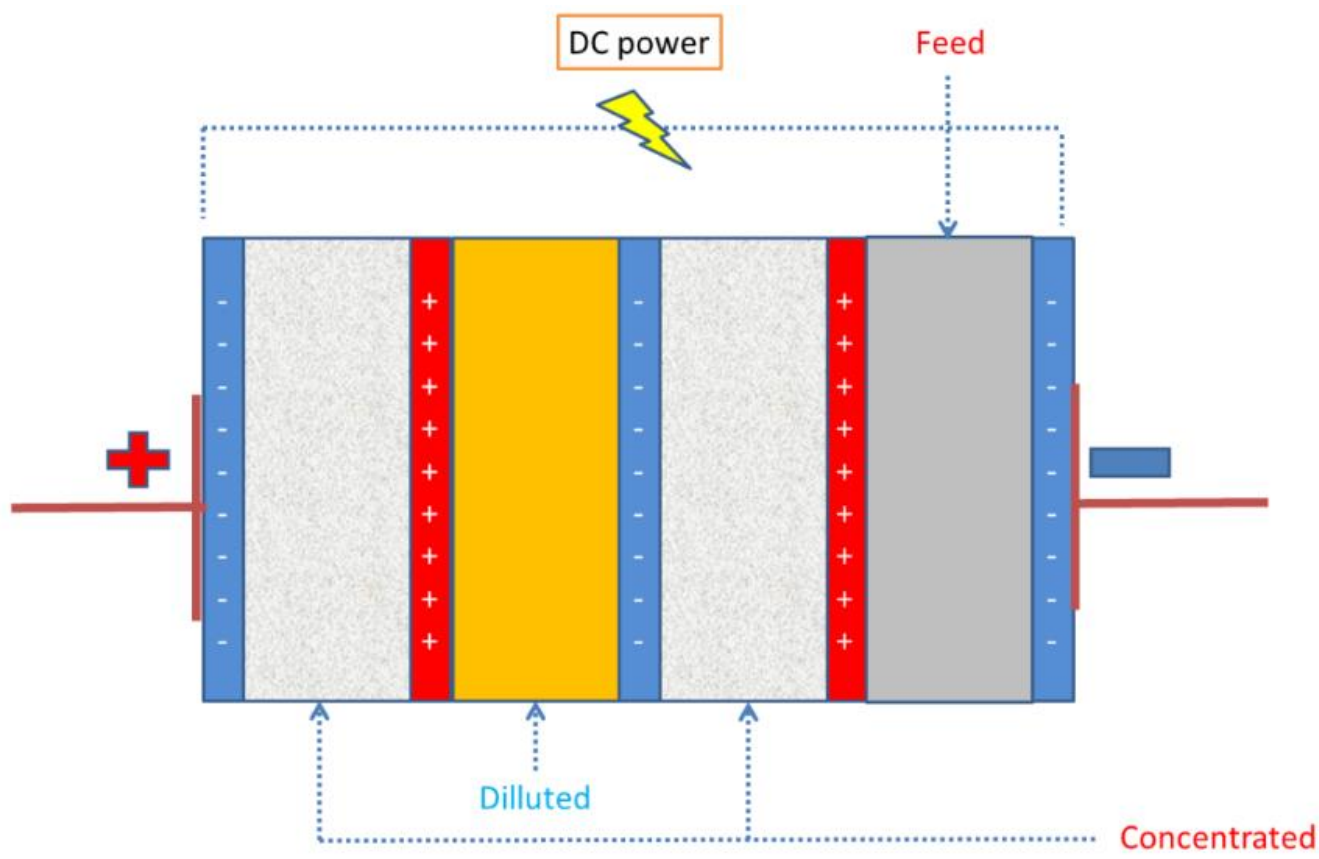

Figure 4. Conventional electrodialysis set up for wastewater treatment.

ED offers the food industry three distinct advantages: better food safety, increased economic competitiveness, and increased environmental friendliness. The most frequent use of ED in the food industry covers extracting some resourceful materials from the effluents instead of only purifying the effluents. However, a few studies are focused on particular food industry wastewater treatment through the use of ED technology. In general, food wastewater contains a large amount of organic matter that is not easy to remove by applying conventional technologies. In this context, Valero et al. [101] used a laboratory-scale ED and performed a series of experiments in order to reduce the organic matter and conductivity simultaneously from wastewater by the almond industry. Initial and final TOC analysis of the dilute and concentrate confirmed the movement of organic anions over the membrane. For instance, the TOC dilute solution drops from 272 to $93 \mathrm{mg} / \mathrm{L}$, whereas for the concentrate, TOC increased from 12 to $268 \mathrm{mg} / \mathrm{L}$, which indicate that the most organic material is transmitted through the membrane and that the solution of dilution decreases both its conductivity and organic content. Besides, ED was also effectively reduced COD (85-90\%) and acids and bases regeneration from salt-rich food industrial effluents [102].

\subsection{Forward Osmosis}

FO is an emerging water treatment membrane-based technology, which has been widely explored in the last few decades both from academic and industrial perspectives. FO is a process by which water passes from the feed solution to the drawing solution due to 
osmotic pressure difference (from low to high) over a semi-permeable FO membrane, and as a result, this process does not require physical/hydraulic pressure during the operation (Figure 5). During the osmotic process, when the feed solution and draw solution reach equilibrium, water permeation is observed from the feed solution to the draw solution through the FO membrane. Because of this, the draw solution is dilute, and the feed solution is concentrated throughout the procedure $[103,104]$. The advantages of FO have been stated in the comparison to reverse osmosis (RO) processes to include fewer membrane fouling and improved energy efficiency [105].

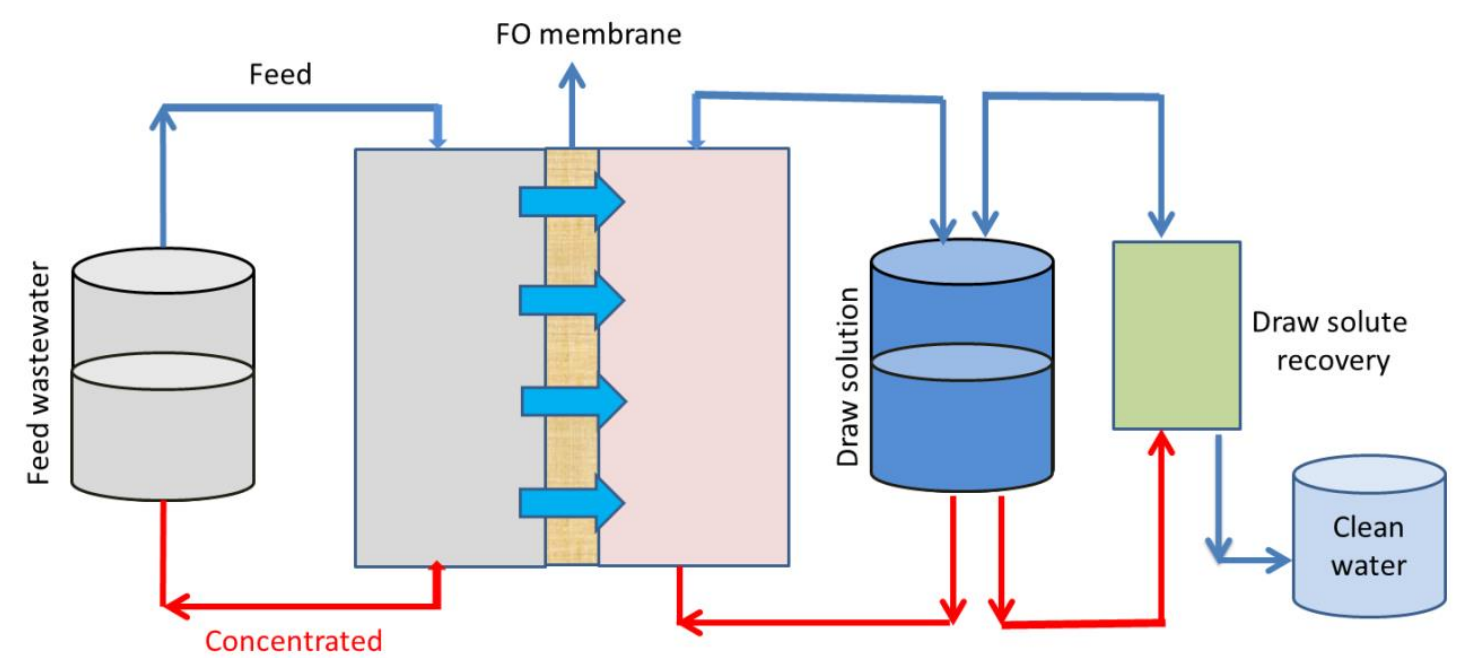

Figure 5. Forward osmosis (FO) process treatment.

FO membrane process is capable of removing nearly all of dissolved ions and suspended particles in a solution. The massive reductions of solids reduced power consumption by half of the succeeding low-pressure FO process. Previously, food wastewater from different sources has been treated with the FO process. For instance, Gebreyohannes et al. [106] applied a single-step FO process to treat olive mill wastewater effluent. The FO treatment resulted in nearly complete decolorization, ion retention, and TOC and TIC rejection rates of $96 \%$ and $99 \%$, respectively. In addition, total phenolic rejection was found to be greater than $98 \%$ in dried residue from FO streams. In parallel to this, the general applicability of the FO process in treating dairy and sugarcane molasses distillery wastewater effluents were also examined $[107,108]$. The obtained results showed that $80-90 \%$ of COD has ultimately been rejected upon the use of FO. The FO process is apparently shown to have potential in treating food wastewater, however, many researchers suggested that the standalone FO process is facing some challenges such as lower efficiency, and economic viability. Hence, FO integrated with other competitive membrane operations such as nanofiltration, reverse osmosis, membrane distillation, and electrodialysis would be suitable process intensification candidates for enhancing their overall performance in purifying wastewater.

\subsection{Electrospun Nanofiber Membranes}

The latest generation of membranes is known as electrospun nanofiber membranes (diameter usually less than $100 \mathrm{~nm}$ ) and have the potential to offer an advancement in the treatment of water and wastewater. In electrospinning, the electrostatic forces help create thinner fibers whereby a high voltage is delivered to a syringe containing a polymer solution or melt that assist in collecting the fibers on a ground plate $[109,110]$. The produced nanofiber membrane has a significant water permeability and flexibility, as well as high porosity, a large surface area to volume ratio, and high-water absorption. Many different features can affect the electrospun nanofibers. The properties of polymers, solutions, and processes are typically categorized into three classes the type of polymer used, its molecular weight, and the distribution of its molecular weight. The solution attributes 
include the type of solvent used, the rate at which the solvent evaporates, as well as the viscosity, concentration and surface tension of the solution. The parameters of the process include flow rate, voltage applied, nozzle tip-to-collector distance, room temperature, and relative humidity.

However, developing a feasible electrospinning technology capable of producing homogeneous nanofibers membranes on a wide scale remains a major issue. In this context, several scaled-up technologies have been introduced in recent years. For example, Chen et al. [111] reported a continuous antibacterial electrospinning nanofibers membrane through the use of a roll-to-roll scale-up post functionalization approach. The process's capacity to scale and the technical difficulties that have been investigated so far show that free-surface technologies have great scaling-up volume potential. Centrifugal electrospinning, has also been shown to be capable of producing nanofibers with diameters as small as $100 \mathrm{~nm}$. Co-axial and multi-axial technologies, on the other hand, can achieve greater material and processing flexibility and, as a result, more diverse functionalities in the resulting nanofibers. These technologies also allow for scale-up production when multi-needle approaches are combined appropriately to deal with multi-jet instabilities [112]. In addition, several companies such as Inovenso (www.inovenso.com, accessed on: 30 November 2021), Mecc Co. (www.mecc.co.jp, accessed on: 30 November 2021), E-Spin Nanotech (www.espinnanotech.com, accessed on: 30 November 2021) and Elmarco (www.elmarco.com, accessed on: 30 November 2021) have started to produce large scale electrospun nanofiber membranes, leading the up-scaling trend. Consequently, massproduction of continuous nanofiber membranes will also be realized for treating food wastewater effluents.

Electrospun nanofiber membranes are rarely utilized for the treatment of food industry wastewater effluent, despite being successfully applied in removing toxic dyes from aqueous effluent, which is surprising since real food industrial effluent contains the same substances in large amount. Particularly, methylene blue (MB) is a popular azo dye with a cationic nature and a good candidate since it is used in textile, paper, leather, cosmetics, plastics and rubber industries. Furthermore, it is also used in food processing equipment preparation such as cutlery, roasters, paper plates, food packaging and food additives. MB is a color pollutant causing eye burns that may result in irreversible eye damage to people and animals. People with lung problems may suffer from intense palpitations or wheezing after breathing MB, and if consumed orally it causes high temperature, nausea, vomiting, heavy sweating, mental confusion, and methemoglobinemia. Thus, MB-contained food industry wastewater effluent needs purification, and it is important to be investigated using electrospun nanofiber membranes (Table 4).

Adsorptive removal of $\mathrm{MB}$ through the use of electrospun nanofiber membrane has been widely investigated in recent years. Adsorption refers to the process by which molecules are transferred from one fluid bulk to another on a solid surface. This might happen as a result of chemical bonding interactions (chemical sorption) and physical forces (physical sorption) [113]. Compared to other techniques, adsorption has been proven to be superior in terms of flexibility, ease of operation, cost-effectiveness and insensitivity to harmful contaminants. In the adsorption process, the adsorbent should have a high specific surface area and porosity, in this case, electrospun nanofiber membrane-based adsorbents exhibit high efficiency of dye removal over conventional phase inversion membranes because of their high specific surface area and linked porosity. For example, Wang et al. [114] prepared sodium alginate-based water-insoluble electrospun nanofiber membrane and cross-linked it with trifluoroacetic acid (TFA), glutaraldehyde vapor (GA) and calcium chloride $\left(\mathrm{CaCl}_{2}\right)$ for $\mathrm{MB}$ removal. It was noticed that $\mathrm{CaCl} 2$ cross-linked nanofiber showed a maximum $\mathrm{MB}$ adsorption capacity of $2230 \mathrm{mg} / \mathrm{g}$, which is attributed to the high specific surface area of the membrane obtained by the cross-linking approach. In another study, Zhao et al. [115] developed thermal cross-linked $\beta$-cyclodextrin-based nanofibers and obtained a maximum adsorption capacity of MB with an amount of $826.45 \mathrm{mg} / \mathrm{g}$, which 
was higher than pure $\beta$-cyclodextrin adsorbent $(105 \mathrm{mg} / \mathrm{g})$. The existence of $-\mathrm{COOH}$ groups in the membrane surface influence the adsorption performances.

The surface functionalization method has been playing a vital role in improving the removal capacity of $\mathrm{MB}$ using electrospun nanofiber membranes. Incorporating functional groups onto the nanofiber membrane surface provided a substantial amount of active binding sites for $\mathrm{MB}$ adsorption. For example, the adsorption capacity of oxidized carbon nanofibers membrane was higher $(\mathrm{MB}, 168 \mathrm{mg} / \mathrm{g})$ compared to the pristine carbon nanofibers membrane $(\mathrm{MB}, 48.8 \mathrm{mg} / \mathrm{g}$ ) because of the electrostatic interactions that occurred between the electrospun nanofibers membranes [116]. Plasma etching has been revealed as a green surface functionalization technology and promoted the adsorption performance of electrospun nanofibers membranes. Bai et al. [117] fabricated air plasmaassisted PLLA nanofibrous membranes and showed that electrostatic interaction was mainly responsible for the high adsorption of $\mathrm{MB}$. They suggested that other electrospun nanofibers membranes could be used for further development, and plasma operations should be optimized.

The fabrication of metal-doped electrospun nanofiber membranes can now be considered as a robust tool for the development of nanofiber-based heterogeneous catalysts towards MB degradation. This can be performed by following either pre- or post-modification strategies. For example, Shalan et al. [118] prepared Ag/Fe co-doped cellulose acetate electrospun nanofiber using a pre-modification approach and degraded MB (more than $95 \%$ ) via photocatalysis reaction. The degradation process of MB was carried out within a very short time (50 min) and exhibited good reusability capacity up to 5 cycles, with the composite doped membrane showing outstanding mechanical properties. Cheng et al. [119] used a post-surface-modified electrospun nanofiber membrane whereby they first prepared a cellulose acetate nanofiber membrane and deacetylated it through a $\mathrm{NaOH}$ solution. Next, the deacetylated membrane was coated with polydopamine (PDA) and immediately applied for MB removal. Results suggest that the deprotonation of the phenol group from the PDA presented a negative charge and effectively captured positively charged $\mathrm{MB}$ due to electrostatic interaction forces. Overall, it implies that modulation of design and fabrication strategy could be a powerful perspective to improve the performance of electrospun nanofibers membranes towards wastewater treatment.

Table 4. Applications of electrospun nanofiber membranes in MB removal.

\begin{tabular}{|c|c|c|c|c|}
\hline Membrane Materials & Membrane Characteristics & Operational Conditions & $\begin{array}{l}\text { Adsorption Capacity, } \mathrm{q}_{\mathrm{e}} \\
\max (\mathrm{mg} / \mathrm{g})\end{array}$ & Ref. \\
\hline $\begin{array}{l}\text { Sodium alginate (SA), poly } \\
\text { (ethylene oxide) (PEO) }\end{array}$ & $\begin{array}{l}\text { Fiber diameter }=150 \mathrm{~nm}, \\
\text { surface area }=13.97 \mathrm{~m}^{2} / \mathrm{g}\end{array}$ & $\begin{array}{l}\text { Initial MB conc. }=200 \text { to } \\
1500 \mathrm{mg} / \mathrm{L}, \mathrm{V}=50 \mathrm{~mL}, \mathrm{pH}=6, \\
\text { adsorbent weight }=20 \mathrm{mg}\end{array}$ & 2230 & [114] \\
\hline $\begin{array}{l}\beta \text {-cyclodextrin, poly(acrylic } \\
\text { acid) (PAA) }\end{array}$ & $\begin{array}{l}\text { Fiber diameter }=20.56 \mathrm{~nm}, \\
\text { surface area }=34.88 \mathrm{~m}^{2} / \mathrm{g}\end{array}$ & $\begin{array}{c}\text { Initial } \mathrm{MB} \text { conc. }=40 \mathrm{mg} / \mathrm{L} \\
\mathrm{V}=80 \mathrm{~mL}, \mathrm{pH}=9, \text { adsorbent } \\
\text { weight }=6 \mathrm{mg}\end{array}$ & 826.45 & [115] \\
\hline $\begin{array}{l}\text { Plasma etched poly(l-lactic } \\
\text { acid) (PLLA) }\end{array}$ & $\begin{array}{l}\text { Fiber diameter }=\mathrm{N} / \mathrm{A} \text {, surface } \\
\quad \text { area }=22.84 \mathrm{~m}^{2} / \mathrm{g}\end{array}$ & $\begin{array}{c}\text { Initial } \mathrm{MB} \text { conc. }=4 \mathrm{mg} / \mathrm{L} \\
\mathrm{V}=3 \mathrm{~mL}, \mathrm{pH}=\mathrm{N} / \mathrm{A} \\
\text { adsorbent weight }=10 \mathrm{mg}\end{array}$ & 8.73 & [117] \\
\hline $\begin{array}{l}\text { Poly(vinyl alcohol) } \\
\text { (PVA)/starch }\end{array}$ & $\begin{array}{l}\text { Fiber diameter }=350-450, \\
\text { surface area }=45.61 \mathrm{~m}^{2} / \mathrm{g}\end{array}$ & $\begin{array}{c}\text { Initial MB conc. }=250 \mathrm{mg} / \mathrm{L} \\
\mathrm{V}=60 \mathrm{~mL}, \mathrm{pH}=8.5 \\
\text { adsorbent weight }=5 \mathrm{mg}\end{array}$ & 400 & [120] \\
\hline Polyacrylonitrile (PAN) & $\begin{array}{c}\text { Fiber diameter }=250-300, \\
\text { surface area }=\mathrm{N} / \mathrm{A}\end{array}$ & $\begin{array}{c}\text { Initial } \mathrm{MB} \text { conc. }=25 \mathrm{mg} / \mathrm{L} \\
\mathrm{V}=10 \mathrm{~mL}, \mathrm{pH}=10, \text { adsorbent } \\
\text { weight }=7 \mathrm{mg}\end{array}$ & 72.46 & [121] \\
\hline $\begin{array}{c}\text { Hydroxypropyl- } \beta \text { - } \\
\text { cyclodextrin (HP } \beta C D) \text { and } \\
\text { benzoxazine monomer (BA-a) }\end{array}$ & $\begin{array}{c}\text { Fiber diameter }=\mathrm{N} / \mathrm{A} \text {, surface } \\
\text { area }=\mathrm{N} / \mathrm{A}\end{array}$ & $\begin{array}{c}\text { Initial } \mathrm{MB} \text { conc. }=10-100 \mathrm{mg} / \mathrm{L} \\
\mathrm{V}=5 \mathrm{~mL}, \mathrm{pH}=\mathrm{N} / \mathrm{A} \\
\text { adsorbent weight }=5 \mathrm{mg}\end{array}$ & 46 & [122] \\
\hline $\begin{array}{l}\text { Sericin/-cyclodextrin/poly } \\
\text { (vinyl alcohol) }\end{array}$ & $\begin{array}{c}\text { Fiber diameter }=\mathrm{N} / \mathrm{A}, \text { surface } \\
\text { area }=\mathrm{N} / \mathrm{A}\end{array}$ & $\begin{array}{c}\text { Initial } \mathrm{MB} \text { conc. }=20 \mathrm{mg} / \mathrm{L} \\
\mathrm{V}=80 \mathrm{~mL}, \mathrm{pH}=8, \text { adsorbent } \\
\text { weight }=14 \mathrm{mg}\end{array}$ & 187 & [123] \\
\hline $\begin{array}{l}\text { Poly-L-lactic acid (pLLA), } \\
\text { polyaniline (PANI) }\end{array}$ & $\begin{array}{l}\text { Fiber diameter }=518 \mathrm{~nm}, \\
\text { surface area }=7.0 \pm 0.4\end{array}$ & $\begin{array}{c}\text { Initial } \mathrm{MB} \text { conc. }=250 \mathrm{mg} / \mathrm{L} \\
\mathrm{V}=10 \mathrm{~mL}, \mathrm{pH}=6, \text { adsorbent } \\
\text { weight }=10 \mathrm{mg}\end{array}$ & 239 & [124] \\
\hline
\end{tabular}


Table 4. Cont

\begin{tabular}{|c|c|c|c|c|}
\hline Membrane Materials & Membrane Characteristics & Operational Conditions & $\begin{array}{l}\text { Adsorption Capacity, } \mathrm{q}_{\mathrm{e}}, \\
\max (\mathrm{mg} / \mathrm{g})\end{array}$ & Ref. \\
\hline $\begin{array}{l}\text { Polyacrylonitrile (PAN), } \\
\text { polyaniline (PANI) }\end{array}$ & $\begin{array}{l}\text { Fiber diameter }=418 \mathrm{~nm}, \\
\text { surface area }=10.0 \pm 0.3\end{array}$ & $\begin{array}{c}\text { Initial } \mathrm{MB} \text { conc. }=250 \mathrm{mg} / \mathrm{L}, \\
\mathrm{V}=10 \mathrm{~mL}, \mathrm{pH}=6, \text { adsorbent } \\
\text { weight }=10 \mathrm{mg}\end{array}$ & 398 & [124] \\
\hline polyacrylonitrile (PAN) & $\begin{aligned} \text { Fiber diameter } & =225 \mathrm{~nm}, \\
\text { surface area } & =\mathrm{N} / \mathrm{A}\end{aligned}$ & $\begin{array}{c}\text { Initial } \mathrm{MB} \text { conc. }=400 \mathrm{mg} / \mathrm{L} \\
\mathrm{V}=10 \mathrm{~mL}, \mathrm{pH}=\mathrm{N} / \mathrm{A} \\
\text { adsorbent weight }=10 \mathrm{mg}\end{array}$ & 42 & [125] \\
\hline $\begin{array}{c}\text { ethylenediamine } \\
\text { (EDA)-grafted } \\
\text { polyacrylonitrile (PAN) }\end{array}$ & $\begin{aligned} \text { Fiber diameter } & =230 \mathrm{~nm}, \\
\text { surface area } & =\mathrm{N} / \mathrm{A}\end{aligned}$ & $\begin{array}{c}\text { Initial } \mathrm{MB} \text { conc. }=400 \mathrm{mg} / \mathrm{L} \\
\mathrm{V}=10 \mathrm{~mL}, \mathrm{pH}=\mathrm{N} / \mathrm{A} \\
\text { adsorbent weight }=10 \mathrm{mg}\end{array}$ & 94 & [125] \\
\hline $\begin{array}{l}\text { Oxime grafted } \\
\text { polyacrylonitrile (OX-g-PAN) }\end{array}$ & $\begin{aligned} \text { Fiber diameter } & =231 \mathrm{~nm}, \\
\text { surface area } & =\mathrm{N} / \mathrm{A}\end{aligned}$ & $\begin{array}{c}\text { Initial } \mathrm{MB} \text { conc. }=400 \mathrm{mg} / \mathrm{L} \\
\mathrm{V}=10 \mathrm{~mL}, \mathrm{pH}=6, \text { adsorbent } \\
\text { weight }=10 \mathrm{mg}\end{array}$ & 102 & [126] \\
\hline Cellulose acetate (CA) & $\begin{array}{l}\text { Fiber diameter }=752 \pm 311 \mathrm{~nm}, \\
\quad \text { surface area }=\mathrm{N} / \mathrm{A}\end{array}$ & $\begin{array}{c}\text { Initial } \mathrm{MB} \text { conc. }=30 \mathrm{mg} / \mathrm{L} \\
\mathrm{V}=100 \mathrm{~mL}, \mathrm{pH}=8, \text { adsorbent } \\
\text { weight }=80 \mathrm{mg}\end{array}$ & 45 & [127] \\
\hline $\begin{array}{c}\text { Cellulose acetate } \\
(\mathrm{CA}) / \text { polyaniline } / \\
\beta \text {-cyclodextrin (PANI } \beta \text {-CD) }\end{array}$ & $\begin{array}{l}\text { Fiber diameter }=1085 \pm 325 \mathrm{~nm} \\
\quad \text { surface area }=\mathrm{N} / \mathrm{A}\end{array}$ & $\begin{array}{c}\text { Initial } \mathrm{MB} \text { conc. }=30 \mathrm{mg} / \mathrm{L} \\
\mathrm{V}=100 \mathrm{~mL}, \mathrm{pH}=8, \text { adsorbent } \\
\text { weight }=80 \mathrm{mg}\end{array}$ & 49 & [127] \\
\hline
\end{tabular}

\section{Membrane Fouling}

Membrane fouling is by far the most important phenomenon limiting the application of membrane separation processing in industry. The occurrence of membrane fouling is due to membrane pore narrowing, pore blockage, and cake layer formation on the membrane surface due to the interaction of microbial metabolites, organic and inorganic substances, and microorganisms [128]. Membrane fouling can be irreversible or reversible based on the extent of fouling and the possibility to regenerate the membrane by different membrane cleaning approaches. Irreversible and reversible fouling issues are partly cured by chemical and physical cleaning strategies, respectively [129]. For example, NF and reverse osmosis membranes are prepared from dense materials, are more susceptible to fouling, while porous MF and UF membranes can be physically cleaned by backwashing rather easily, aeration or chemically cleaned with acid and/or base [130]. Lately, electrospun nanofiber membranes face also fouling issues such as irreversible, reversible and biofouling. Several factors such as membrane properties, feed characteristics, operation conditions, and various foulants have led to a complex fouling formations [131]. Membrane fouling lowers membrane permeate flux and therefore limits the removal efficiency of pollutants during application. Membrane fouling mainly occurs by organic compounds and macromolecules such as pectins, starch, glucose and other substances in food industrial wastewater effluents. The literature shows that food industrial wastewater effluents are often related to irreversible and reversible fouling phenomena, especially reversible fouling dominates in potato processing wastewater treatment plants, as reported by Bouchareb et al. [132]. Usually, this could be managed by chemical cleaning and backwashing, and by pre-treatment. However, generally speaking there is still a lack of understanding of the relationship between removal efficiency and fouling in food industrial wastewater effluents which needs to be immediate addressed.

\section{Challenges and Perspectives}

Membranes are used as sustained solutions for treating wastewater, but several issues still interfere with their effective processing and limit their wider application. Membrane fouling always remains the main challenge that is strongly needed to be handled by scientific research. Technological challenges in terms of productivity, product quality, and socio-political issues, namely climate change, related to energy consumption and greenhouse gas emissions, is also a matter of concern for the membrane technology [133]. In specific terms, electrospun nanofiber membranes needs improving their mechanical properties and stability over long-term operation. New substances with tailored permeable characteristics are required for effectively treating and recovering water effluent in the food 
industry by developing of lighter, cheaper and less power consuming materials than those of current technologies.

\section{Conclusions}

The use and performance of different membrane materials and processes for the treatment of wastewater in the food industry is critically discussed. The findings of this paper encompass all the main concepts, performance and challenges of MBRs, MD, pressure-driven membrane filtration, ED, FO and newly developed electrospun nanofiber membranes. It has been found that electrospun nanofibers membranes can eliminate organic pollutants such as methylene blue dyes from food wastewater. Mainly, the adsorptive removal process using electrospun nanofiber membranes is shown as the most prominent with a maximum capacity of $2230 \mathrm{mg} / \mathrm{g}$. Despite all the efforts made, the most difficult aspect of using membrane technology is controlling fouling, which needs to be sorted out by developing novel strategies. Importantly, up-scaling of electrospun nanofiber membrane production for the treatment of food industry wastewater effluent should be urgently investigated because we have shown its potential benefits compared to currently used 1 technologies.

Author Contributions: Conceptualization, M.N.P. and V.N.; formal analysis, M.N.P., M.R.M. and G.K.S.; writing-original draft and final paper preparation, M.N.P. and M.R.M.; writing-review and editing, G.K.S., S.W.H., Y.Z., Y.C., T.Z., V.B. and V.N.; supervision, V.N.; project administration, V.N.; funding acquisition, V.N. All authors have read and agreed to the published version of the manuscript.

Funding: We wish to express our sincere gratitude to the support from the Sanitary Environmental Engineering Division (SEED) and grants (FARB projects) from the University of Salerno, Italy, coordinated by prof. V. Naddeo. The Ph.D School in "Risk and Sustainability in Civil Engineering, Environmental and Construction" is also acknowledged for the scholarships (cycle-XXXIV) of M.N. Pervez.

Institutional Review Board Statement: Not applicable.

Informed Consent Statement: Not applicable.

Data Availability Statement: The datasets generated during the current study are available from the corresponding author on reasonable request (Vincenzo Naddeo, V.N.).

Conflicts of Interest: The authors declare no conflict of interest.

\section{References}

1. Awange, J. Lake Victoria Monitored from Space; Springer: Cham, Swizterland; Gewerbestr, Germany, 2021.

2. Tapera, M. Towards greener preservation of edible oils: A mini-review. Asian J. Appl. Chem. Res. 2019, 4, 1-8. [CrossRef]

3. Pervez, M.N.; Wei, Y.; Sun, P.; Qu, G.; Naddeo, V.; Zhao, Y. $\alpha$-FeOOH quantum dots impregnated graphene oxide hybrids enhanced arsenic adsorption: The mediation role of environmental organic ligands. Sci. Total Environ. 2021, 781, 146726. [CrossRef]

4. Pervez, M.N.; Fu, D.; Wang, X.; Bao, Q.; Yu, T.; Naddeo, V.; Tian, H.; Cao, C.; Zhao, Y. A bifunctional $\alpha$-FeOOH@GCA nanocomposite for enhanced adsorption of arsenic and photo Fenton-like catalytic conversion of As(III). Environ. Technol. Innov. 2021, 22, 101437. [CrossRef]

5. Naddeo, V.; Korshin, G. Water, energy and waste: The great European deal for the environment. Sci. Total. Environ. 2021, 764, 142911. [CrossRef]

6. Pervez, M.N.; He, W.; Zarra, T.; Naddeo, V.; Zhao, Y. New Sustainable Approach for the Production of Fe3O4/Graphene Oxide-Activated Persulfate System for Dye Removal in Real Wastewater. Water 2020, 12, 733. [CrossRef]

7. Jing, J.; Pervez, M.N.; Sun, P.; Cao, C.; Li, B.; Naddeo, V.; Jin, W.; Zhao, Y. Highly efficient removal of bisphenol A by a novel Co-doped LaFeO3 perovskite/PMS system in salinity water. Sci. Total Environ. 2021, 801, 149490. [CrossRef] [PubMed]

8. Naddeo, V. One planet, one health, one future: The environmental perspective. Water Environ. Res. 2021, 93, 1472-1475. [CrossRef] [PubMed]

9. Naddeo, V:; Liu, H. Editorial Perspectives: 2019 novel coronavirus (SARS-CoV-2): What is its fate in urban water cycle and how can the water research community respond? Environ. Sci.-Water Res. Technol. 2020, 6, 1939. [CrossRef]

10. Walsh, B.P.; Cusack, D.O.; O'Sullivan, D.T.J. An industrial water management value system framework development. Sustain. Prod. Consum. 2016, 5, 82-93. [CrossRef] 
11. Flörke, M.; Kynast, E.; Bärlund, I.; Eisner, S.; Wimmer, F.; Alcamo, J. Domestic and industrial water uses of the past 60 years as a mirror of socio-economic development: A global simulation study. Glob. Environ. Chang. 2013, 23, 144-156. [CrossRef]

12. Compton, M.; Willis, S.; Rezaie, B.; Humes, K. Food processing industry energy and water consumption in the Pacific northwest. Innov. Food Sci. Emerg. Technol. 2018, 47, 371-383. [CrossRef]

13. Jing, J.; Cao, C.; Ma, S.; Li, Z.; Qu, G.; Xie, B.; Jin, W.; Zhao, Y. Enhanced defect oxygen of $\mathrm{LaFeO}_{3} / \mathrm{GO}$ hybrids in promoting persulfate activation for selective and efficient elimination of bisphenol A in food wastewater. Chem. Eng. J. 2021, 407, 126890. [CrossRef]

14. Sakcharoen, T.; Ratanatamskul, C.; Chandrachai, A. Factors affecting technology selection, techno-economic and environmental sustainability assessment of a novel zero-waste system for food waste and wastewater management. J. Clean. Prod. 2021, 314, 128103. [CrossRef]

15. Barbera, M.; Gurnari, G. Wastewater Treatment and Reuse in the Food Industry; Springer: Cham, Swizterland; Gewerbestr, Germany, 2018.

16. Sellaoui, L.; Dhaouadi, F.; Li, Z.; Cadaval, T.R., Jr.; Igansi, A.V.; Pinto, L.A.; Dotto, G.L.; Bonilla-Petriciolet, A.; Pinto, D.; Chen, Z. Implementation of a multilayer statistical physics model to interpret the adsorption of food dyes on a chitosan film. J. Environ. Chem. Eng. 2021, 9, 105516. [CrossRef]

17. Leifeld, V.; Dos Santos, T.P.M.; Zelinski, D.W.; Igarashi-Mafra, L. Ferrous ions reused as catalysts in Fenton-like reactions for remediation of agro-food industrial wastewater. J. Environ. Manag. 2018, 222, 284-292. [CrossRef] [PubMed]

18. Pervez, M.N.; Telegin, F.Y.; Cai, Y.; Xia, D.; Zarra, T.; Naddeo, V. Efficient Degradation of Mordant Blue 9 Using the FentonActivated Persulfate System. Water 2019, 11, 2532. [CrossRef]

19. Norton, T.; Misiewicz, P. Ozone for water treatment and its potential for process water reuse in the food industry. In Ozone in Food Processing; O’Donnell, C., Tiwari, B.K., Cullen, P.J., Rice, R.G., Eds.; Wiley-Blackwell: Hoboken, NJ, USA, 2012 ; pp. 177-199.

20. Li, S.; Zhao, S.; Yan, S.; Qiu, Y.; Song, C.; Li, Y.; Kitamura, Y. Food processing wastewater purification by microalgae cultivation associated with high value-added compounds production-A review. Chin. J. Chem. Eng. 2019, 27, 2845-2856. [CrossRef]

21. Sehar, S. Wastewater treatment of food industries through constructed wetland: A review. Int. J. Environ. Sci. Technol. 2020, 17, 4667-4668. [CrossRef]

22. De Nardi, I.R.; Del Nery, V.; Amorim, A.K.B.; dos Santos, N.G.; Chimenes, F. Performances of SBR, chemical-DAF and UV disinfection for poultry slaughterhouse wastewater reclamation. Desalination 2011, 269, 184-189. [CrossRef]

23. Patange, A.; Boehm, D.; Giltrap, M.; Lu, P.; Cullen, P.J.; Bourke, P. Assessment of the disinfection capacity and eco-toxicological impact of atmospheric cold plasma for treatment of food industry effluents. Sci. Total Environ. 2018, 631-632, 298-307. [CrossRef]

24. Cecconet, D.; Molognoni, D.; Callegari, A.; Capodaglio, A.G. Agro-food industry wastewater treatment with microbial fuel cells: Energetic recovery issues. Int. J. Hydrogen Energy 2018, 43, 500-511. [CrossRef]

25. Valta, K.; Kosanovic, T.; Malamis, D.; Moustakas, K.; Loizidou, M. Overview of water usage and wastewater management in the food and beverage industry. Desalination Water Treat. 2015, 53, 3335-3347. [CrossRef]

26. Asgharnejad, H.; Khorshidi Nazloo, E.; Madani Larijani, M.; Hajinajaf, N.; Rashidi, H. Comprehensive review of water management and wastewater treatment in food processing industries in the framework of water-food-environment nexus. Compr. Rev. Food Sci. Food Saf. 2021, 45, 19642-19663. [CrossRef]

27. Morshed, M.N.; Pervez, M.N.; Behary, N.; Bouazizi, N.; Guan, J.; Nierstrasz, V.A. Statistical modeling and optimization of heterogeneous Fenton-like removal of organic pollutant using fibrous catalysts: A full factorial design. Sci. Rep. 2020, 10, 16133. [CrossRef]

28. Millanar-Marfa, J.M.J.; Borea, L.; Castrogiovanni, F.; Hasan, S.W.; Choo, K.-H.; Korshin, G.V.; de Luna, M.D.G.; Ballesteros, F.C., Jr.; Belgiorno, V.; Naddeo, V. Self-forming Dynamic Membranes for Wastewater Treatment. Sep. Purif. Rev. 2021, 1-17. [CrossRef]

29. Pervez, M.N.; Balakrishnan, M.; Hasan, S.W.; Choo, K.-H.; Zhao, Y.; Cai, Y.; Zarra, T.; Belgiorno, V.; Naddeo, V. A critical review on nanomaterials membrane bioreactor (NMs-MBR) for wastewater treatment. NPJ Clean Water 2020, 3, 43. [CrossRef]

30. Ng, L.Y.; Chua, H.S.; Ng, C.Y. Incorporation of graphene oxide-based nanocomposite in the polymeric membrane for water and wastewater treatment: A review on recent development. J. Environ. Chem. Eng. 2021, 9, 105994. [CrossRef]

31. Ng, C.Y.; Khoo, L.H.; Ng, L.Y.; Ong, C.B.; Mahmoudi, E.; Rohani, R.; Mohammad, A.W. Novel polyethersulfone-cellulose composite thin film using sustainable empty fruit bunches from Elaeis guineensis for methylene blue removal. Polym. Test. 2020, 86, 106494. [CrossRef]

32. Li, S.; Li, Y.; Wei, C.; Wang, P.; Gao, P.; Zhou, L.; Wen, G. One step co-sintering of silicon carbide ceramic membrane with the aid of boron carbide. J. Eur. Ceram. Soc. 2021, 41, 1181-1188. [CrossRef]

33. Molodkina, L.M.; Kolosova, D.D.; Leonova, E.I.; Kudoyarov, M.F.; Patrova, M.Y.; Vedmetskii, Y.V. Track membranes in posttreatment of domestic wastewater. Pet. Chem. 2012, 52, 487-493. [CrossRef]

34. Zhang, Q.; Wang, H.; Fan, X.; Chen, S.; Yu, H.; Quan, X. A controlled wet-spinning and dip-coating process for preparation of high-permeable TiO2 hollow fiber membranes. Water Sci. Technol. 2015, 73, 725-733. [CrossRef] [PubMed]

35. Pervez, M.N.; Stylios, G.K. An Experimental Approach to the Synthesis and Optimisation of a 'Green' Nanofibre. Nanomaterials 2018, 8, 383. [CrossRef] [PubMed]

36. Pervez, M.N.; Stylios, G.K. Investigating the Synthesis and Characterization of a Novel "Green" $\mathrm{H}_{2} \mathrm{O}_{2}$-Assisted, Water-Soluble Chitosan/Polyvinyl Alcohol Nanofiber for Environmental End Uses. Nanomaterials 2018, 8, 395. [CrossRef] [PubMed] 
37. Pervez, M.N.; Stylios, G.K.; Liang, Y.; Ouyang, F.; Cai, Y. Low-temperature synthesis of novel polyvinylalcohol (PVA) nanofibrous membranes for catalytic dye degradation. J. Clean. Prod. 2020, 262, 121301. [CrossRef]

38. Bjorge, D.; Daels, N.; De Vrieze, S.; Dejans, P.; Van Camp, T.; Audenaert, W.; Hogie, J.; Westbroek, P.; De Clerck, K.; Van Hulle, S.W.H. Performance assessment of electrospun nanofibers for filter applications. Desalination 2009, 249, 942-948. [CrossRef]

39. Lotfikatouli, S.; Hadi, P.; Yang, M.; Walker, H.W.; Hsiao, B.S.; Gobler, C.; Reichel, M.; Mao, X. Enhanced anti-fouling performance in Membrane Bioreactors using a novel cellulose nanofiber-coated membrane. Sep. Purif. Technol. 2021, 275, 119145. [CrossRef]

40. Wang, R.; Liu, Y.; Li, B.; Hsiao, B.S.; Chu, B. Electrospun nanofibrous membranes for high flux microfiltration. J. Membr. Sci. 2012, 392-393, 167-174. [CrossRef]

41. Dobosz, K.M.; Kuo-Leblanc, C.A.; Martin, T.J.; Schiffman, J.D. Ultrafiltration membranes enhanced with electrospun nanofibers exhibit improved flux and fouling resistance. Ind. Eng. Chem. Res. 2017, 56, 5724-5733. [CrossRef] [PubMed]

42. Shen, K.; Cheng, C.; Zhang, T.; Wang, X. High performance polyamide composite nanofiltration membranes via reverse interfacial polymerization with the synergistic interaction of gelatin interlayer and trimesoyl chloride. J. Membr. Sci. 2019, 588, 117192. [CrossRef]

43. Zhou, T.; Li, J.; Guo, X.; Yao, Y.; Zhu, P.; Xiang, R. Freestanding PTFE electrospun tubular membrane for reverse osmosis brine concentration by vacuum membrane distillation. Desalin. Water Treat 2019, 165, 63-72. [CrossRef]

44. Zheng, G.; Jiang, J.; Wang, X.; Li, W.; Liu, J.; Fu, G.; Lin, L. Nanofiber membranes by multi-jet electrospinning arranged as arc-array with sheath gas for electrodialysis applications. Mater. Des. 2020, 189, 108504. [CrossRef]

45. Deka, B.J.; Lee, E.-J.; Guo, J.; Kharraz, J.; An, A.K. Electrospun Nanofiber Membranes Incorporating PDMS-Aerogel Superhydrophobic Coating with Enhanced Flux and Improved Antiwettability in Membrane Distillation. Environ. Sci. Technol. 2019, 53, 4948-4958. [CrossRef] [PubMed]

46. Kim, S.; Heath, D.E.; Kentish, S.E. Improved carbon dioxide stripping by membrane contactors using hydrophobic electrospun poly(vinylidene fluoride-co-hexafluoro propylene) (PVDF-HFP) membranes. Chem. Eng. J. 2022, 428, 131247. [CrossRef]

47. Obaid, M.; Abdelkareem, M.A.; Kook, S.; Kim, H.-Y.; Hilal, N.; Ghaffour, N.; Kim, I.S. Breakthroughs in the fabrication of electrospun-nanofiber-supported thin film composite/nanocomposite membranes for the forward osmosis process: A review. Crit. Rev. Environ. Sci. Technol. 2020, 50, 1727-1795. [CrossRef]

48. Aderibigbe, D.O.; Giwa, A.-R.A.; Bello, I.A. Characterization and treatment of wastewater from food processing industry: A review. IMAM J. Appl. Sci. 2017, 2, 27.

49. Qiu, Y.; Zu, Y.; Song, C.; Xie, M.; Qi, Y.; Kansha, Y.; Kitamura, Y. Soybean processing wastewater purification via Chlorella L166 and L38 with potential value-added ingredients production. Bioresour. Technol. Rep. 2019, 7, 100195. [CrossRef]

50. Karadag, D.; Köroğlu, O.E.; Ozkaya, B.; Cakmakci, M. A review on anaerobic biofilm reactors for the treatment of dairy industry wastewater. Process Biochem. 2015, 50, 262-271. [CrossRef]

51. Beltrán-Heredia, J.; Torregrosa, J.; García, J.; Dominguez, J.R.; Tierno, J.C. Degradation of olive mill wastewater by the combination of Fenton's reagent and ozonation processes with an aerobic biological treatment. Water Sci. Technol. 2001, 44, 103-108. [CrossRef]

52. Chatzipaschali, A.A.; Stamatis, A.G. Biotechnological utilization with a focus on anaerobic treatment of cheese whey: Current status and prospects. Energies 2012, 5, 3492-3525. [CrossRef]

53. Sroka, E.; Kamiński, W.; Bohdziewicz, J. Biological treatment of meat industry wastewater. Desalination 2004, 162, 85-91. [CrossRef]

54. Arantes, M.K.; Alves, H.J.; Sequinel, R.; da Silva, E.A. Treatment of brewery wastewater and its use for biological production of methane and hydrogen. Int. J. Hydrogen Energy 2017, 42, 26243-26256. [CrossRef]

55. De Carvalho, J.C.; Borghetti, I.A.; Cartas, L.C.; Woiciechowski, A.L.; Soccol, V.T.; Soccol, C.R. Biorefinery integration of microalgae production into cassava processing industry: Potential and perspectives. Bioresour. Technol. 2018, 247, 1165-1172. [CrossRef]

56. Barrera-Díaz, C.; Roa-Morales, G.; Ávila-Córdoba, L.; Pavón-Silva, T.; Bilyeu, B. Electrochemical Treatment Applied to FoodProcessing Industrial Wastewater. Ind. Eng. Chem. Res. 2006, 45, 34-38. [CrossRef]

57. Chiacchierini, E.; Restuccia, D.; Vinci, G. Bioremediation of Food Industry Effluents: Recent Applications of Free and Immobilised Polyphenoloxidases. Food Sci. Technol. Int. 2004, 10, 373-382. [CrossRef]

58. Qasim, W.; Mane, A.V. Characterization and treatment of selected food industrial effluents by coagulation and adsorption techniques. Water Resour. Ind. 2013, 4, 1-12. [CrossRef]

59. Benamar, A.; Mahjoubi, F.Z.; Barka, N.; Kzaiber, F.; Boutoial, K.; Ali, G.A.M.; Oussama, A. Olive mill wastewater treatment using infiltration percolation in column followed by aerobic biological treatment. SN Appl. Sci. 2020, 2, 655. [CrossRef]

60. Değermenci, N.; Cengiz, İ.; Yildiz, E.; Nuhoglu, A. Performance investigation of a jet loop membrane bioreactor for the treatment of an actual olive mill wastewater. J. Environ. Manag. 2016, 184, 441-447. [CrossRef] [PubMed]

61. Bustillo-Lecompte, C.; Mehrvar, M.; Quiñones-Bolaños, E. Slaughterhouse wastewater characterization and treatment: An economic and public health necessity of the meat processing industry in Ontario, Canada. J. Geosci. Environ. Prot. 2016, 4, 175-186. [CrossRef]

62. Puchlik, M.; Struk-Sokołowska, J. Comparison of the Composition of Wastewater from Fruit and Vegetables as well as Dairy Industry. In Proceedings of the E3S Web of Conferences, 9th Conference on Interdisciplinary Problems in Environmental Protection and Engineering EKO-DOK 2017, Boguszow Gorce, Bialystok, Poland; EDP Sciences: Les Ulis, France, 2017 ; p. 77.

63. Ahmad, N.N.R.; Ang, W.L.; Leo, C.P.; Mohammad, A.W.; Hilal, N. Current advances in membrane technologies for saline wastewater treatment: A comprehensive review. Desalination 2021, 517, 115170. [CrossRef] 
64. Nayyar, D.; Nawaz, T.; Noore, S.; Singh, A.P. Food Processing Wastewater Treatment: Current Practices and Future Challenges. In Pollution Control Technologies; Springer: Berlin/Heidelberg, Germany, 2021; pp. 177-208.

65. Melin, T.; Jefferson, B.; Bixio, D.; Thoeye, C.; De Wilde, W.; de Koning, J.; van der Graaf, J.; Wintgens, T. Membrane bioreactor technology for wastewater treatment and reuse. Desalination 2006, 187, 271-282. [CrossRef]

66. Al-Asheh, S.; Bagheri, M.; Aidan, A. Membrane bioreactor for wastewater treatment: A review. Case Stud. Chem. Environ. Eng. 2021, 4, 100109. [CrossRef]

67. Goswami, L.; Vinoth Kumar, R.; Borah, S.N.; Arul Manikandan, N.; Pakshirajan, K.; Pugazhenthi, G. Membrane bioreactor and integrated membrane bioreactor systems for micropollutant removal from wastewater: A review. J. Water Process Eng. 2018, 26, 314-328. [CrossRef]

68. Neoh, C.H.; Noor, Z.Z.; Mutamim, N.S.A.; Lim, C.K. Green technology in wastewater treatment technologies: Integration of membrane bioreactor with various wastewater treatment systems. Chem. Eng. J. 2016, 283, 582-594. [CrossRef]

69. He, Y.; Xu, P.; Li, C.; Zhang, B. High-concentration food wastewater treatment by an anaerobic membrane bioreactor. Water Res. 2005, 39, 4110-4118. [CrossRef]

70. Wang, Y.; Huang, X.; Yuan, Q. Nitrogen and carbon removals from food processing wastewater by an anoxic/aerobic membrane bioreactor. Process Biochem. 2005, 40, 1733-1739. [CrossRef]

71. Galib, M.; Elbeshbishy, E.; Reid, R.; Hussain, A.; Lee, H.-S. Energy-positive food wastewater treatment using an anaerobic membrane bioreactor (AnMBR). J. Environ. Manag. 2016, 182, 477-485. [CrossRef]

72. Katayon, S.; Megat Mohd Noor, M.J.; Ahmad, J.; Abdul Ghani, L.A.; Nagaoka, H.; Aya, H. Effects of mixed liquor suspended solid concentrations on membrane bioreactor efficiency for treatment of food industry wastewater. Desalination 2004, 167, 153-158. [CrossRef]

73. Acharya, C.; Nakhla, G.; Bassi, A.; Kurian, R. Treatment of High-Strength Pet Food Wastewater Using Two-Stage Membrane Bioreactors. Water Environ. Res. 2006, 78, 661-670. [CrossRef] [PubMed]

74. Acharya, C.; Nakhla, G.; Bassi, A. Operational Optimization and Mass Balances in a Two-Stage MBR Treating High Strength Pet Food Wastewater. J. Environ. Eng. 2006, 132, 810-817. [CrossRef]

75. Mahat, S.B.; Omar, R.; Che Man, H.; Mohamad Idris, A.I.; Mustapa Kamal, S.M.; Idris, A.; Shreeshivadasan, C.; Jamali, N.S.; Abdullah, L.C. Performance of dynamic anaerobic membrane bioreactor (DAnMBR) with phase separation in treating high strength food processing wastewater. J. Environ. Chem. Eng. 2021, 9, 105245. [CrossRef]

76. Van Der Bruggen, B.; Vandecasteele, C.; Van Gestel, T.; Doyen, W.; Leysen, R. A review of pressure-driven membrane processes in wastewater treatment and drinking water production. Environ. Prog. 2003, 22, 46-56. [CrossRef]

77. Hube, S.; Eskafi, M.; Hrafnkelsdóttir, K.F.; Bjarnadóttir, B.; Bjarnadóttir, M.Á.; Axelsdóttir, S.; Wu, B. Direct membrane filtration for wastewater treatment and resource recovery: A review. Sci. Total Environ. 2020, 710, 136375. [CrossRef]

78. Ochando-Pulido, J.M.; Martinez-Ferez, A. A focus on pressure-driven membrane technology in olive mill wastewater reclamation: State of the art. Water Sci. Technol. 2012, 66, 2505-2516. [CrossRef] [PubMed]

79. Muro, C.; Riera, F.; del Carmen Díaz, M. Membrane separation process in wastewater treatment of food industry. In Food Industrial Processes-Methods and Equipment; InTech: Rijeka, Croatia, 2012; pp. 253-280.

80. Hart, M.R.; Huxsoll, C.C.; Tsai, I.-S.; Ng, K.C. Preliminary Studies of Microfiltration for Food Processing Water Reuse1. J. Food Prot. 1988, 51, 269-276. [CrossRef] [PubMed]

81. Kumar, R.V.; Goswami, L.; Pakshirajan, K.; Pugazhenthi, G. Dairy wastewater treatment using a novel low cost tubular ceramic membrane and membrane fouling mechanism using pore blocking models. J. Water Process Eng. 2016, 13, 168-175. [CrossRef]

82. Hua, F.L.; Tsang, Y.F.; Wang, Y.J.; Chan, S.Y.; Chua, H.; Sin, S.N. Performance study of ceramic microfiltration membrane for oily wastewater treatment. Chem. Eng. J. 2007, 128, 169-175. [CrossRef]

83. Zielińska, M.; Galik, M. Use of Ceramic Membranes in a Membrane Filtration Supported by Coagulation for the Treatment of Dairy Wastewater. Water Air Soil Pollut. 2017, 228, 173. [CrossRef] [PubMed]

84. Cui, Z.F.; Jiang, Y.; Field, R.W. Fundamentals of pressure-driven membrane separation processes. In Membrane Technology; Cui, Z.F., Muralidhara, H.S., Eds.; Elsevier: Amsterdam, The Netherlands, 2010; pp. 1-18.

85. Zulaikha, S.; Lau, W.J.; Ismail, A.F.; Jaafar, J. Treatment of restaurant wastewater using ultrafiltration and nanofiltration membranes. J. Water Process Eng. 2014, 2, 58-62. [CrossRef]

86. Ochando-Pulido, J.M.; Rodriguez-Vives, S.; Hodaifa, G.; Martinez-Ferez, A. Impacts of operating conditions on reverse osmosis performance of pretreated olive mill wastewater. Water Res. 2012, 46, 4621-4632. [CrossRef] [PubMed]

87. Vourch, M.; Balannec, B.; Chaufer, B.; Dorange, G. Treatment of dairy industry wastewater by reverse osmosis for water reuse. Desalination 2008, 219, 190-202. [CrossRef]

88. Coskun, T.; Debik, E.; Demir, N.M. Treatment of olive mill wastewaters by nanofiltration and reverse osmosis membranes. Desalination 2010, 259, 65-70. [CrossRef]

89. Giacobbo, A.; Meneguzzi, A.; Bernardes, A.M.; de Pinho, M.N. Pressure-driven membrane processes for the recovery of antioxidant compounds from winery effluents. J. Clean. Prod. 2017, 155, 172-178. [CrossRef]

90. Alkhudhiri, A.; Darwish, N.; Hilal, N. Membrane distillation: A comprehensive review. Desalination 2012, 287, 2-18. [CrossRef]

91. Alsebaeai, M.K.; Ahmad, A.L. Membrane distillation: Progress in the improvement of dedicated membranes for enhanced hydrophobicity and desalination performance. J. Ind. Eng. Chem. 2020, 86, 13-34. [CrossRef] 
92. Anvari, A.; Azimi Yancheshme, A.; Kekre, K.M.; Ronen, A. State-of-the-art methods for overcoming temperature polarization in membrane distillation process: A review. J. Membr. Sci. 2020, 616, 118413. [CrossRef]

93. Drioli, E.; Ali, A.; Macedonio, F. Membrane distillation: Recent developments and perspectives. Desalination 2015, 356, 56-84. [CrossRef]

94. El-Abbassi, A.; Kiai, H.; Hafidi, A.; García-Payo, M.C.; Khayet, M. Treatment of olive mill wastewater by membrane distillation using polytetrafluoroethylene membranes. Sep. Purif. Technol. 2012, 98, 55-61. [CrossRef]

95. El-Abbassi, A.; Hafidi, A.; Khayet, M.; García-Payo, M.C. Integrated direct contact membrane distillation for olive mill wastewater treatment. Desalination 2013, 323,31-38. [CrossRef]

96. El-Abbassi, A.; Khayet, M.; Kiai, H.; Hafidi, A.; García-Payo, M.C. Treatment of crude olive mill wastewaters by osmotic distillation and osmotic membrane distillation. Sep. Purif. Technol. 2013, 104, 327-332. [CrossRef]

97. Garcia-Castello, E.; Cassano, A.; Criscuoli, A.; Conidi, C.; Drioli, E. Recovery and concentration of polyphenols from olive mill wastewaters by integrated membrane system. Water Res. 2010, 44, 3883-3892. [CrossRef] [PubMed]

98. Luiz, A.; McClure, D.D.; Lim, K.; Leslie, G.; Coster, H.G.L.; Barton, G.W.; Kavanagh, J.M. Potential upgrading of bio-refinery streams by electrodialysis. Desalination 2017, 415, 20-28. [CrossRef]

99. Huang, C.; Xu, T. Electrodialysis with bipolar membranes for sustainable development. Environ. Sci. Technol. 2006, 40, 5233-5243. [CrossRef]

100. Al-Amshawee, S.; Yunus, M.Y.B.M.; Azoddein, A.A.M.; Hassell, D.G.; Dakhil, I.H.; Hasan, H.A. Electrodialysis desalination for water and wastewater: A review. Chem. Eng. J. 2020, 380, 122231. [CrossRef]

101. Valero, D.; García-García, V.; Expósito, E.; Aldaz, A.; Montiel, V. Application of electrodialysis for the treatment of almond industry wastewater. J. Membr. Sci. 2015, 476, 580-589. [CrossRef]

102. Hestekin, J.; Ho, T.; Potts, T. Electrodialysis in the food industry. In Membrane Technology: Volume 3: Membranes for Food Applications, Volume 3; Wiley: Hoboken, NJ, USA, 2010; Volume 3, pp. 75-104.

103. Chung, T.-S.; Li, X.; Ong, R.C.; Ge, Q.; Wang, H.; Han, G. Emerging forward osmosis (FO) technologies and challenges ahead for clean water and clean energy applications. Curr. Opin. Chem. Eng. 2012, 1, 246-257. [CrossRef]

104. Francis, L.; Ogunbiyi, O.; Saththasivam, J.; Lawler, J.; Liu, Z. A comprehensive review of forward osmosis and niche applications. Environ. Sci. Water Res. Technol. 2020, 6, 1986-2015. [CrossRef]

105. Zamani, F.; Chew, J.W.; Akhondi, E.; Krantz, W.B.; Fane, A.G. Unsteady-state shear strategies to enhance mass-transfer for the implementation of ultrapermeable membranes in reverse osmosis: A review. Desalination 2015, 356, 328-348. [CrossRef]

106. Gebreyohannes, A.Y.; Curcio, E.; Poerio, T.; Mazzei, R.; Di Profio, G.; Drioli, E.; Giorno, L. Treatment of Olive Mill Wastewater by Forward Osmosis. Sep. Purif. Technol. 2015, 147, 292-302. [CrossRef]

107. Haupt, A.; Lerch, A. Forward osmosis treatment of effluents from dairy and automobile industry-Results from short-term experiments to show general applicability. Water Sci. Technol. 2018, 78, 467-475. [CrossRef]

108. Singh, N.; Petrinic, I.; Hélix-Nielsen, C.; Basu, S.; Balakrishnan, M. Influence of Forward Osmosis (FO) membrane properties on dewatering of molasses distillery wastewater. J. Water Process Eng. 2019, 32, 100921. [CrossRef]

109. Talukder, M.E.; Pervez, M.N.; Jianming, W.; Gao, Z.; Stylios, G.K.; Hassan, M.M.; Song, H.; Naddeo, V. Chitosan-functionalized sodium alginate-based electrospun nanofiber membrane for As (III) removal from aqueous solution. J. Environ. Chem. Eng. 2021, 9, 106693. [CrossRef]

110. Talukder, M.E.; Hasan, K.M.F.; Wang, J.; Yao, J.; Li, C.; Song, H. Novel fibrin functionalized multilayered electrospun nanofiber membrane for burn wound treatment. J. Mater. Sci. 2021, 56, 12814-12834. [CrossRef]

111. Chen, K.; Nikam, S.P.; Zander, Z.K.; Hsu, Y.-H.; Dreger, N.Z.; Cakmak, M.; Becker, M.L. Continuous Fabrication of Antimicrobial Nanofiber Mats Using Post-Electrospinning Functionalization for Roll-to-Roll Scale-Up. ACS Appl. Polym. Mater. 2020, 2, 304-316. [CrossRef]

112. Persano, L.; Camposeo, A.; Tekmen, C.; Pisignano, D. Industrial Upscaling of Electrospinning and Applications of Polymer Nanofibers: A Review. Macromol. Mater. Eng. 2013, 298, 504-520. [CrossRef]

113. Hossain, M.Y.; Zhu, W.; Pervez, M.N.; Yang, X.; Sarker, S.; Hassan, M.M.; Hoque, M.I.U.; Naddeo, V.; Cai, Y. Adsorption, kinetics, and thermodynamic studies of cacao husk extracts in waterless sustainable dyeing of cotton fabric. Cellulose 2021, 28, 2521-2536. [CrossRef]

114. Wang, Q.; Ju, J.; Tan, Y.; Hao, L.; Ma, Y.; Wu, Y.; Zhang, H.; Xia, Y.; Sui, K. Controlled synthesis of sodium alginate electrospun nanofiber membranes for multi-occasion adsorption and separation of methylene blue. Carbohydr. Polym. 2019, 205, 125-134. [CrossRef] [PubMed]

115. Zhao, R.; Wang, Y.; Li, X.; Sun, B.; Wang, C. Synthesis of $\beta$-Cyclodextrin-Based Electrospun Nanofiber Membranes for Highly Efficient Adsorption and Separation of Methylene Blue. ACS Appl. Mater. Interfaces 2015, 7, 26649-26657. [CrossRef]

116. Thamer, B.M.; El-Hamshary, H.; Al-Deyab, S.S.; El-Newehy, M.H. Functionalized electrospun carbon nanofibers for removal of cationic dye. Arab. J. Chem. 2019, 12, 747-759. [CrossRef]

117. Bai, L.; Jia, L.; Yan, Z.; Liu, Z.; Liu, Y. Plasma-etched electrospun nanofiber membrane as adsorbent for dye removal. Chem. Eng. Res. Des. 2018, 132, 445-451. [CrossRef]

118. Shalan, A.E.; Afifi, M.; El-Desoky, M.M.; Ahmed, M.K. Electrospun nanofibrous membranes of cellulose acetate containing hydroxyapatite co-doped with Ag/Fe: Morphological features, antibacterial activity and degradation of methylene blue in aqueous solution. New J. Chem. 2021, 45, 9212-9220. [CrossRef] 
119. Cheng, J.; Zhan, C.; Wu, J.; Cui, Z.; Si, J.; Wang, Q.; Peng, X.; Turng, L.-S. Highly Efficient Removal of Methylene Blue Dye from an Aqueous Solution Using Cellulose Acetate Nanofibrous Membranes Modified by Polydopamine. ACS Omega 2020, 5, 5389-5400. [CrossRef] [PubMed]

120. Moradi, E.; Ebrahimzadeh, H.; Mehrani, Z.; Asgharinezhad, A.A. The efficient removal of methylene blue from water samples using three-dimensional poly (vinyl alcohol)/starch nanofiber membrane as a green nanosorbent. Environ. Sci. Pollut. Res. 2019, 26, 35071-35081. [CrossRef]

121. Ibupoto, A.S.; Qureshi, U.A.; Ahmed, F.; Khatri, Z.; Khatri, M.; Maqsood, M.; Brohi, R.Z.; Kim, I.S. Reusable carbon nanofibers for efficient removal of methylene blue from aqueous solution. Chem. Eng. Res. Des. 2018, 136, 744-752. [CrossRef]

122. Dogan, Y.E.; Satilmis, B.; Uyar, T. Crosslinked PolyCyclodextrin/PolyBenzoxazine electrospun microfibers for selective removal of methylene blue from an aqueous system. Eur. Polym. J. 2019, 119, 311-321. [CrossRef]

123. Zhao, R.; Wang, Y.; Li, X.; Sun, B.; Jiang, Z.; Wang, C. Water-insoluble sericin/ $\beta$-cyclodextrin/PVA composite electrospun nanofibers as effective adsorbents towards methylene blue. Colloids Surf. B Biointerfaces 2015, 136, 375-382. [CrossRef]

124. Mohammad, N.; Atassi, Y. Adsorption of methylene blue onto electrospun nanofibrous membranes of polylactic acid and polyacrylonitrile coated with chloride doped polyaniline. Sci. Rep. 2020, 10, 13412. [CrossRef] [PubMed]

125. Haider, S.; Binagag, F.F.; Haider, A.; Mahmood, A.; Shah, N.; Al-Masry, W.A.; Khan, S.U.-D.; Ramay, S.M. Adsorption kinetic and isotherm of methylene blue, safranin $\mathrm{T}$ and rhodamine $\mathrm{B}$ onto electrospun ethylenediamine-grafted-polyacrylonitrile nanofibers membrane. Desalination Water Treat. 2015, 55, 1609-1619. [CrossRef]

126. Haider, S.; Binagag, F.F.; Haider, A.; Al-Masry, W.A. Electrospun oxime-grafted-polyacrylonitrile nanofiber membrane and its application to the adsorption of dyes. J. Polym. Res. 2014, 21, 371. [CrossRef]

127. Ali, A.S.M.; El-Aassar, M.R.; Hashem, F.S.; Moussa, N.A. Surface Modified of Cellulose Acetate Electrospun Nanofibers by Polyaniline/ $\beta$-cyclodextrin Composite for Removal of Cationic Dye from Aqueous Medium. Fibers Polym. 2019, 20, 2057-2069. [CrossRef]

128. Guo, W.; Ngo, H.-H.; Li, J. A mini-review on membrane fouling. Bioresour. Technol. 2012, 122, 27-34. [CrossRef]

129. Wang, Z.; Ma, J.; Tang, C.Y.; Kimura, K.; Wang, Q.; Han, X. Membrane cleaning in membrane bioreactors: A review. J. Membr. Sci. 2014, 468, 276-307. [CrossRef]

130. Shirazi, S.; Lin, C.-J.; Chen, D. Inorganic fouling of pressure-driven membrane processes-A critical review. Desalination 2010, 250, 236-248. [CrossRef]

131. Subrahmanya, T.M.; Arshad, A.B.; Lin, P.T.; Widakdo, J.; Makari, H.K.; Austria, H.F.; Hu, C.C.; Lai, J.Y.; Hung, W.S. A review of recent progress in polymeric electrospun nanofiber membranes in addressing safe water global issues. RSC Adv. 2021, 11, 9638-9663.

132. Bouchareb, R.; Bilici, Z.; Dizge, N. Potato Processing Wastewater Treatment Using a Combined Process of Chemical Coagulation and Membrane Filtration. CLEAN-Soil Air Water 2021, 49, 2100017. [CrossRef]

133. Fane, A.G. Membranes and the water cycle: Challenges and opportunities. Appl. Water Sci. 2011, 1, 3-9. [CrossRef] 